\title{
Kurumsal Yönetim Endeksinde Yer Alan ve Yer Almayan İşletmelerde Finansal Performansın Getiri Üzerindeki Etkisinin İncelenmesi
}

\author{
Seyhan ÖZTÜRK ${ }^{1}$, Sevgül EKİNCİ ${ }^{2}$ ve Tuncer YILMAZ ${ }^{3}$
}

\section{Öz}

Son yıllarda oldukça önem kazanmış bir kavram olan kurumsal yönetim; iyi yönetim uygulamaları olarak anılmakta ve işletmelere ciddi avantajlar yaratmaktadır. Kurumsal yönetim kavramı ile finansal performansın getirilere olan etkisini araştıran bu çalışmada; inceleme kapsamında yer alan işletmeler iki grup halinde ele alınmıştır. Birinci grupta BİST Kurumsal Yönetim (XKURY) Endeksinde yer alan, ikinci grupta ise BISST Kurumsal Yönetim Endeksinde yer almayan işletmeler bulunmaktadır. Bu iki işletme grubuna ait finansal oranların hisse senedi getirileri üzerindeki etkisini analiz edip, bir farklılık olup olmadığını tespit edip karşılaştırmak çalışmanın temel çıkış noktasını oluşturmaktadır. Çalışmada likidite, etkinlik, kârllıı ve piyasa ölçümleri olarak 14 finansal oran, 1 tane de kontrol değişkeni kullanılmıştır. Analizlerde işletmelerin 2013-2018 dönemine ait yıllık verileri kullanılmıştır. İnceleme döneminde verileri sürekli olan toplam 190 işletme araştırma kapsamında yer almaktadır. Bu işletmelerin 39’u Kurumsal Yönetim Endeksinde yer alan, 151’i ise Kurumsal Yönetim Endeksinde yer almayan işletmelerden oluşmaktadır. İşletmelere ait finansal oranlar ile kontrol değişkeni bağımsız, hisse senedi getirileri ise bağımlı değişken olarak alınarak iki farklı regresyon modeli ile analiz edilmiştir. Yapılan analizlerden elde edilen sonuçlara göre; Kurumsal Yönetim Endeksinde yer alan işletmelere ait finansal oranların hisse senedi getirilerini \%13,7 oranında açıklarken, Kurumsal Yönetim Endeksinde yer almayan işletmelerde ise aynı finansal oranlar şirketlerin hisse senedi getirilerini açıklama oranı \% 4,9 olduğu tespit edilmiştir.

Anahtar Kelimeler: Kurumsal Yönetim, Finansal Oranlar, Getiri, BİST.

Investigation of the Effect of Financial Performance on Incorporation Companies within the Corporate Governance Index

\begin{abstract}
In recent years, the concept of corporate governance, a concept that has gained considerable importance; is known as good management practices and creates serious advantages for enterprises. In this study, which unifies the effects of financial performance on returns with corporate governance concept; the enterprises are divided into two groups. In the first group, the enterprises included in the BIST Corporate Governance (XKURY) Index and in the second group which are not included in the BIST Corporate Governance Index. Analyzing the effect of financial ratios of these two business groups on stock returns, determining whether there is a difference or not is the main starting point of the study. The study covers 14 financial ratios and 1 control variable used as liquidity, efficiency, profitability and market measurements. Annual data of the enterprises are used for the period of 2013-2018. In the review period, a total of 190 enterprises which have continuous data are included in the research. 39 of these enterprises are included in Corporate Governance Index and 151 of the enterprises are not included in Corporate Governance Index. The financial ratios of the enterprises and the control variable were analyzed independently and the stock returns were analyzed by two different regression models. According to the results obtained from the analyzes, the ratio of the financial ratios of the enterprises included in the Corporate Governance Index to the ratio was $13.7 \%$, while the rate of disclosure of the stock returns of the companies in the companies not included in the Corporate Governance Index was found to be $4.9 \%$.
\end{abstract}

Key Words: Corporate Governance, Financial Rations, Return, BIST.

\author{
Atıf İçin / Please Cite As: \\ Öztürk, S., Ekinci, S. ve Yılmaz, T. (2020). Kurumsal yönetim endeksinde yer alan ve yer almayan işletmelerde \\ finansal performansın getiri üzerindeki etkisinin incelenmesi. Manas Sosyal Araştırmalar Dergisi, 9(2), 1059- \\ 1069.
}

Geliş Tarihi / Received Date: 28.02.2019

Kabul Tarihi / Accepted Date: 03.09.2019

\footnotetext{
1 Doç. Dr. - Kafkas Üniversitesi, İIBF, İşletme Bölümü, seyhan87ozturk@gmail.com, ORCID ID: 0000-0003-1458-840X

2 Öğr. Gör. - Kafkas Üniversitesi, Susuz Meslek Yüksekokulu, sevgülekinci@gmail.com, ORCID ID: 0000-0003-4099-1948

3 Öğr. Gör. - Kafkas Üniversitesi, Susuz Meslek Yüksekokulu, y1lmaz-tuncer@hotmail.com, ORCID ID: 0000-0001-8956-5814
} 


\section{Giriş}

Son yillarda işletmeler arası rekabet ortamının kızışması, çeşitli muhasebe skandallarının yaşanmış olması kurumsal yönetim kavramının önemini hissedilir düzeylere ulaştırmıştır. Özellikle söz konusu skandallar ve finansal krizlerin temel sebebinin; kurumsal yönetim politikalarının yetersiz olmasına bağlanması bu kavramın önemini daha da artırmıştır. Bu sebeple hem gelişmiş ülkeler hem de gelişmekte olan ülkeler mümkün mertebe, bu konuya dikkat çekmeye ve önemsemeye başlamışlardır. Kurumsal yönetim uygulamalarını benimseyen işletmeler ve organizasyonların bu kavramın yarattığı birçok avantajı yakaladıkları yadsınamaz bir gerçektir. Bu avantajların en önemlileri; işletme performansının artması, sermaye ve finansal kaynaklara düşük maliyetle, kolaylıkla ulaşılması, kaynakların verimli kullanılması, hem işletme hem de ülke imajına olumlu katkı, işletmenin ilgi grupları arasında çıkar çatışmalarının önlenmesi ve sürdürebilirliğin sağlanması şeklinde sayılabilmektedir.

Bu bağlamda kurumsal yönetim kavramı ile finansal performansın getirilere olan etkisini araştıran bu çalışmada amaç; kurumsal yönetim uygulamalarını yürüten ve yürütmeyen işletmelerin finansal performansının getirileri üzerindeki etkilerini ölçmektir. Bu amaç çerçevesinde; inceleme kapsamında yer alan işletmeler iki grup halinde ele alınmıştır. Birinci grupta BİST Kurumsal Yönetim (XKURY) Endeksinde yer alan, ikinci grupta ise BİST Kurumsal Yönetim Endeksinde yer almayan işletmeler bulunmaktadır. Bu iki işletme grubuna ait finansal oranların hisse senedi getirileri üzerindeki etkisi analiz edilerek, bir farklılık olup olmadığını tespit etmek çalışmanın temel çıkış noktasını oluşturmaktadır. Yapılan analizlerden elde edilen sonuçlara göre; Kurumsal Yönetim Endeksinde yer alan işletmelerin finansal oranlarının; hisse senedi getirilerini \%13,7 oranında; Kurumsal Yönetim Endeksinde yer almayan işletmelerin finansal oranlarının ise hisse senedi getirilerini \% 4,9 oranında açıkladığı tespit edilmiştir.

\section{Kurumsal Yönetim}

Kurumsal yönetim kurumsallaşma kavramıyla yakından ilişkili olan günümüzde giderek artan öneme sahip bir kavram olarak öne çıkmaktadır. Bu bağlamda kurumsallaşma; işletmelerin faaliyette bulundukları çevreleriyle uyumlarını, zamanla oluşan bir ilerlemeyi açılamaktadır. Farklı ifadelerle; belli bir çevrede faaliyet gösteren kuruluşların yapı ve işleyiş özellikleri ile çevrenin özellikleri arasındaki paralelliği, örgütsel yapılarda zamanla oluşan benzerliği kurumsallaşma göstermektedir (Yenigün, 2008, s. 3).

1990 'lı yllarda ortaya atılan ve hızlı bir şekilde iş dünyası, uluslararası organizasyonlar, hükümetler ve akademik çevrelerden kabul gören bir yönetim felsefesi haline gelen kurumsal yönetimin özünde, şirketlerin hissedarlarına ve diğer paydaşlara en yüksek yarar sağlayacak şekilde yönetilmeleri bulunmaktadır (Pamukçu, 2011, s. 134).

Kurumsal yönetim; işletmeler tarafından yönlendirilen ve kontrol edilen bir sistem olarak tanımlanabilmektedir. İşletmeler içerisinde süreçler, kontroller, hesap verebilirlik, şeffaflık ve karar alma ile ilgili olan kurumsal yönetim; organizasyonlar için oldukça büyük öneme sahiptir (Zuva ve Zuva, 2018, s. 17).

Kurumsal yönetim; işletmelerin yönetiminde ve faaliyetlerinde katma değer yaratmak, kar sağlamak, elde edilen karları pay sahiplerine dağıtmak gibi klasik amaçlar gütmenin yanında; hissedarlar, çalışanlar, kredi verenler, müşteriler, toplum ve diğer tüm çıkar gruplarının aralarındaki ilişkileri düzenleyen kurallar bütününü ifade etmektedir (Öztürk ve Demirgüneş, 2008, s. 396).

Kurumsal yönetim uygulamaları; bir organizasyonda iki koşul oluştuğunda gerekli olmakta ve ortaya çıkmaktadır. İlk koşul; sahipler, yöneticiler, ortaklar ve hatta müşterilerinde karıştığı çıkar çatışması halidir. İkinci koşul ise; yapılan sözleşme ile dahi çözülemeyen işlem maliyetlerin yarattığı aracılık sorunu halidir (Hart, 1995, s. 678). Bu tür problemlerin oluşması kurumsal yönetimin gerekliliğine zemin hazırlamaktadır.

Kurumsal yönetim uygulamaları; yönetim kurulunun hisse senedi yatırımcılarının menfaatlerine nasıl iyi hizmet edebileceği bakış açısından doğmuştur. Ancak daha sonraki zamanlarda; bütün menfaat sahiplerinin ihtiyaç ve çıkarlarının nasıl en iyi şekilde karşılanabileceği bakış açısına doğru değişme göstermiştir. Kurumsal yönetim uygulamalarında normatif, düzenleyici yönü ağır basan çözümler üretmek yerine, işletme performansındaki yükselişi temel alan ve esnekliğe sahip işletme içi yapılanmalar dikkat çekmektedir (Ulukan, 2004, s. 214-215) 


\section{Literatür Taraması}

Gompers, Ishii ve Metrick (2003) kurumsal yönetim uygulamalarının firmaların hisse senedi getirileri üzerindeki etkisini araştırmışlardır. Bu etkiyi hisse fiyatları, defter değeri ve Tobin Q değişkenlerini kullanarak tespit etmeye çalışmışlardır. Kurumsal yönetim ilkeleri ile hisse senedi getirileri arasında önemli derecede pozitif bir ilişki olduğu sonucuna ulaşmışlardır.

Bebzcuk (2005) kurumsal yönetim ve firma performansı üzerine yaptı̆̆1 çalışmasını iki aşamada gerçekleştirmiş̧ir. İlk aşamada 2003-2004 yıllarında Arjantin'deki finansal olmayan 65 firmanın kurumsal yönetimin kalitesi ve mülkiyet yapısına ilişsin niceliksel önlemleri bir araya getirmiştir. İkinci aşamada ise, bu önlemleri kurumsal performans ve temettü politikası ile ilişkilendirmiştir. Kurumsal performansın belirleyicileri olarak varlık getirisi (ROA) ve Tobin Q değişkenlerini kullanmıştır. Performans konusunda yönetim önleminin hem varlıkların getirisi (ROA) hem de Tobin Q üzerinde oldukça büyük ve güçlü bir etkisi olduğu sonucuna ulaşmıştır.

Niu (2006) kurumsal yönetim mekanizmaları ile muhasebe kazançlarının kalitesi arasındaki ilişkiyi incelemeyi amaçladığı çalışmasında, Kanada'da bir firmanın 2001-2004 yılları arasındaki kurumsal yönetim verilerini kullanmıştır. Bu verilerin analizinde regresyon analizini kullanıış ve analiz sonucunda, kurumsal yönetim kalitesinin getiri-kazanç ilişkisini olumlu yönde etkilediği ortaya çıkmıştır.

Cheng (2008) yaptığı çalışmada, kurumsal yönetim kapsamında yer alan firma yönetim kurulu ile kurumsal performans arasındaki ilişkiyi incelemeye çalısmıştır. Kurumsal performansı değerlendirme noktasinda, aylık hisse senedi getirilerindeki, varlıkların yıllık muhasebe getirisindeki (ROA) ve Tobin Q değerlerindeki değişiklikleri dikkate almıştır. Bu değişkenleri, Yatırımcı Sorumluluk Araştırma Merkezi’nin (IRRC) 1996-2004 döneminde belirlemiş olduğu 1.252 firmaya uygulamıştır. Sonuçta bir firmanın yönetim kurulu büyüdükçe, kurumsal performans ve değerin daha az değişken hale geldiğini tespit etmiştir. Ayrıca yönetim kurulu büyüklügünün; kurumsal hisse senedi performans1, muhasebe performansı (ROA) ve firmanın kurumsal değeri (Tobin Q) standart sapmaları ile önemli ölçüde negatif ilişkili olduğu sonuçlarına ulaşmıştır.

Shen ve Lin (2010) 1994-2004 yllları arasında Tayvan'da faaliyet gösteren 183 üretici firma üzerinde yapmış oldukları çalışmada, kurumsal yönetimin temel bilgi analizi ve hisse senedi getirisi arasındaki ilişkiyi araştırmışlardır. Sonuç olarak, iyi bir kurumsal yönetime sahip firmaların diğerlerine göre daha fazla hisse senedi getirisine sahip oldukları tespit edilmiştir.

Ersoy, Bayrakdaroğlu ve Şamiloğlu (2011) kurumsal yönetim ve firma performansına yönelik yaptıkları çalışmada, 1998-2007 yılları arasında BİST-100 endeksinde faaliyet gösteren 51 firmanın verilerini panel lojistik regresyon modelini kullanarak analiz etmişlerdir. Bu aşamada, performans göstergelerinden olan Tobin Q ve anormal hisse senedi getirilerini bağımlı değişken; kurumsal yönetim değişkenlerini (yönetim kurulunun yapısı ve büyüklüğü, yönetici sahipliği, yabancı sahipliği, sahiplik yapısı, sahiplik yoğunlaşması, denetim komitesi ve yönetim kurulunun bağımsızlığı) de bağımsız değişken olarak ele almışlardır. Analiz sonucunda; sadece yabancı sahipliğinin Tobin Q temelinde firma performansını artırırken, hisse senedi getirilerini azalttı̆̆ ortaya çıkmıstır.

Eyüboğlu (2011) yapmış olduğu çalışmada, kurumsal yönetimin hisse senedi getirileri üzerindeki etkisini ölçmeye çalışmıştır. Bunun için Borsa İstanbul (BİST) Kurumsal Yönetim Endeksi'nde yer alan firmaların, endeks kapsamına girmeden önceki ve sonraki her bir dönem için aylık hisse senedi getirilerinin TL cinsinden ortalamalarını hesaplamıştır. Ortalamaları hesaplanan gruplar arasında anlamlı bir farklılık olup olmadığını tespit etmek için t-testini kullanmıştır. Analiz sonucunda, hisse senedi getiri ortalamaları arasında istatistikî olarak anlamlı bir farklılığın olmadığ1 sonucuna ulaşmıştır.

Kilıç (2011) kurumsal yönetim endeksi kapsamında yer alan firmaların, endeks kapsamına dâhil olmadan beş gün önceki ve sonraki hisse senedi getiri performanslarındaki değişiklikleri CAMP modelini kullanarak incelemiştir. Bu doğrultuda, BİST Kurumsal yönetim endeksine dâhil olan 28 firmanın verileri kullanılmıştır. Analiz sonucunda, bu firmalardan sadece \%60'ının endeks kapsamına dâhil olduğu ilk günlerde pozitif getiri sağladığı, ancak sonrasında bunun herhangi bir anlam ifade etmediği ortaya çıkmışır.

Şengür ve Püskül (2011) kurumsal yönetim ve firma performansına ilişkin yapmış oldukları çalışmada, kurumsal yönetimin ana unsurlarından olan yönetim kurulu ile firma performans gösterge unsurları olan hisse senedi getirisi, fiyat kazanç oranı, hisse başı kazanç, varlı getiri oranı ve özkaynak getiri oranları 
arasındaki ilişskiyi incelemişlerdir. Bu doğrultuda, 2009 yılında BİST kurumsal yönetim endeksinde faaliyet gösteren 24 firmadan aldıkları verileri analize tabi tutmuşlardır. Analiz kapsamında hipotezler oluşturarak t-testi yöntemini uygulamışardır. Analiz sonucunda, iki komiteye (denetim ve kurumsal yönetim) sahip olan firmaların, tek komiteye sahip olanlardan daha fazla hisse senedi getirisine sahip oldukları sonucuna ulaşmışlardır.

Azeem, Hassan ve Kouser (2013) Karaçi Borsa'da işlem gören en büyük 50 firmanın uyguladığ1 kaliteli kurumsal yönetimin firma performansına etkisini panel veri yöntemini kullanarak analiz etmiştir. Analiz sonucunda, kaliteli kurumsal yönetimin hisse senedi getirisini; dolayısıyla firma performansını büyük ölçüde etkilediği ortaya çıkmıstır.

Tsai ve Tung (2014) Tayvan Menkul Kıymetler Borsası'nda işlem gören 137 ileri teknoloji firmasının performansı ile kurumsal yönetim uygulamaları arasındaki ilişkiyi panel veri regresyon analizi yöntemi ile incelemişlerdir. Bu doğrultuda, kurumsal yönetim yapısı ve kaynaklarının doğrudan yabancı yatırım (DYY) taahhüdü ve firma performansı (hisse başına düşen getiri aktif kârll1ık oranı ve özsermaye kârllılı oranları) üzerindeki etkileri araştırılmıştır. Sonuç olarak, hem icra kurulu başkanı (CEO) ikiliğinin hem de devlet payının bir firmanın doğrudan yabancı yatırımı etkilediği ortaya çıkmışır.

Aksu ve Aytekin (2015) 2009-2014 ylları arasında Borsa İstanbul (BİST) Kurumsal Yönetim Endeksi'nde (XKURY) yer alan 50 firmaya yönelik yapmış oldukları çalışmada, firmaların kurumsal yönetim ilkelerine uyum notu ile hisse senedi getirileri arasındaki ilişkiyi incelemeye çalışmışlardır. $\mathrm{Bu}$ doğrultuda, firmaların kurumsal yönetim ilkelerine uyum notunun ilan edildiği tarihten on gün öncesi ve sonrası, daha sonra beş gün öncesi ve sonrasına ait hisse senedi 2. Seans kapanış fiyatlarının logaritmik getiri ortalamalarını hesaplamışlardır. Hesapladıkları ortalamalar arasındaki farklılıkları tespit etmek için ttesti, Kolmogorov Smirnov ve Wilcoxon işaret testlerini kullanmışlardır. Testler sonucunda, 2009 ve 2014 yılları arasında firmaların kurumsal yönetim ilkelerine uyum notunun açıklanmasından önceki ve sonraki hisse senedi getirileri arasında anlamlı farklılıklar olduğu sonucuna ulaşmışlardır. Bu hisse senedi getirileri arasındaki farklılığın kurumsal yönetim ilkelerine uyum notundan meydana gelip gelmediğini tespit etmek amacıyla da olay çalışması yöntemini kullanmışlardır.

Yavuz, Yıldırım ve Elmas (2015) yaptıkları çalışmada, kurumsal yönetim ile hisse senedi getirisi arasındaki ilişkiyi olay çalışması yöntemi ile analiz etmeye çalışmışlardır. Bu doğrultuda, ilk kez 2012 ve 2013 yıllarında BİST kurumsal yönetim endeksi kapsamına dâhil olan 11 firmanın endekse dâhil olmadan on gün öncesi ve sonrasına ait hisse senedi anormal getirilerini hesaplamışlardır. Sonuç olarak, kurumsal yönetim ile hisse senedi getirisi arasındaki ilişki bazı günler negatif, bazı günler pozitif çıkarak karışı bir seyir göstermiştir.

Oral, Polat ve Şit (2017) kurumsal yönetimin hisse senedi getirileri üzerindeki etkisini ölçmeye yönelik yaptıkları çalışmada, kurumsal yönetim endeksinde yer alan 20 firmanın 2010-2014 yılları arasındaki finansal tablo kalemlerinden alınan ve analizde bağımsız değissken olarak kabul edilen finansal kaldıraç oranlarının hisse senedi getirisi üzerindeki etkisini panel veri analiz yöntemini kullanarak incelemeye çalışmışardır. Analiz sonucunda, bu 20 firmanın 8 'inde (\%40) hisse senedi bileşik getirisinin finansal kaldıraç oranı tarafından artış yönünde etkilendiği sonucuna ulaşmışlardır.

Sakarya, Yazgan ve Yıldırım (2017) yaptıkları çalısmada, hisse senetleri BİST'de işlem gören ve kurumsal yönetim endeksi kapsamında yer alan 58 firmanın 2011-2015 dönemine ait kurumsal yönetim derecelendirme notu ile hisse senedi getirileri arasındaki ilişkiyi tespit etmeye çalışmışlardır. Bu doğrultuda, ilişkiyi tespit edebilmek için analiz yöntemi olarak olay çalışması yöntemini kullanmışlardır. Analiz sonucunda, firmaların kurumsal yönetim derecelendirme notunun duyurulması ile hisse senedi getirisi arasında pozitif bir ilisskinin olmadığı sonucuna ulaşmışlardır.

Literatürde kurumsal yönetim ve finans ilişkisini kuran; özellikle kurumsal yönetim uygulamaları ile finansal performans ilişkilendiren çok sayıda yerli ve yabancı çalışma bulunmaktadır. Bunların birçoğunda kurumsal yönetim uygulamalarının finansal performansı ve dolayısıyla getirileri etkilediği yönünde sonuçlar elde edilmiştir.

\section{BİST İşletmeleri Üzerine Uygulama}

Çalışmanın bu kısmında uygulama ile ilgili bilgiler yer almaktadır. Çalışmanın amacı, çalışmanın veri seti, veri toplama yöntemi, bağımsız değişkenlerin bağımlı değişken üzerindeki etkisini tespit etmek için yapılan analizler ve ortaya çıkan bulgulara ait yorumlar aşağıda detaylı olarak sunulmuştur. 


\section{Çalışmanın Amacı}

Son yıllarda işletme başarısının ölçümünde önem kazanan ölçütlerden biri de kurumsal yönetim uygulamalarına ve ilkelerine sahiplik durumudur. Kurumsal yönetimi tam anlamıyla benimseyen işletmeler için; itibar, imaj, müşteri nezdinde olumlu izlenim yaratmak, kaynakların etkin kullanımı, verimlilik ve etkinlik ön plana çıkmaktadır. Ayrıca işletme faaliyetlerinde başarının süreklilik arz etmesi, her alanda istikrarın hâkim olması piyasada rekabet avantajı elde etmeleri için kurumsal yönetim ilkelerinin etkisi günümüzde daha da önemli hale gelmiştir. Bu açıdan kurumsal yönetim anlayışı aynı zamanda işletmeye değer katmayı amaçlayan bir yönetim biçimi olduğu da söylemek mümkündür.

Bu düşünceden yola çıkarak BISTT işletmeleri üzerine yapılan bu çalışmada, BİST’ de işlem gören ve kurumsal yönetim endeksinde yer alan işletmeler ile diğer (kurumsal yönetim endeksinde yer almayan) işletmelere ait öne çıkan finansal oranların hisse senedi getirileri üzerindeki etkisini tespit etmek amaçlanmıştır.

\section{Veri Seti ve Toplama Yöntemi}

Çalışmanın veri setini 2012-2018 tarihleri arasında BİST' de sürekli olarak işlem gören ve BİST kurumsal yönetim endeksinde yer alan ve almayan işletmelerin 6 yıllık verileri oluşturmaktadır. Veri seti oluşturulurken öncelikle BİST Kurumsal Yönetim Endeksinde yer alan şirketler tespit edilmiş, daha sonra bu şirketler BİST Ulusal Tüm Endeksinde yer alan şirketlerin içinden çıkarılmıştır. Çalışmanın yapıldığı tarihte BİST Kurumsal Endekste 48, BİST Ulusal Tüm Endeksinde ise 323 işletmenin faaliyet gösterdiği tespit edilmiştir. Ulusal Tüm Endeksten Kurumsal Endekse ait 48 işletme çıkarıldığında geriye 275 işletme kalmaktadır. Fakat inceleme döneminde verileri sürekli olmayan veya veri setinin dağılımı bozan başka bir deyişle çarpıklığa neden olan işletmeler çıkarıldığında Kurumsal endekste 39, Ulusal Tüm Endekste ise 151 işletme kalmıştır.

Çalışma kapsamında yer alan 190 işletmeye ait veri seti toplamda 17.100 gözlemden oluşmaktadır. Bu gözlemlerin 3.510’u Kurumsal Yönetim Endeksinde yer alan 39 işletmenin, 13.590 gözlem ise Ulusal Tüm Endeksinde yer alan 151 işletmeye aittir. Toplamda 190 işletmeye ait bu veri seti Finnet firmasına ait olan Hisse Expert programıla öncelikle Microsoft Office Excel ortamına indirilmiş, daha sonra bu veriler düzenlenerek istatistik programları aracıllı̆̆yla analizler yapılmıştır.

İşletmelerin 2013-2018 dönemine ait finansal oranların getiri üzerindeki etkisini tespit etmek için likidite, etkinlik, kârlılık ve piyasa ölçümlerinden yararlanılmıştır. Finansal oranların hesaplanması, kısaltmalar, içinde yer aldıkları ölçümler ve bu oranlara ait açıklamalar Tablo 1'de yer almaktadır.

Tablo 1. Calısmada Yer Alan Finansal Oranlara Ait Bilgiler

\begin{tabular}{|c|c|c|c|}
\hline Kisaltma & Oran Hesaplaması & Ölçümler & Açılklama \\
\hline cao & Dönen Varlıklar/Kısa Vadeli Yabancı Kaynaklar & \multirow{2}{*}{$\begin{array}{l}\text { Likidite } \\
\text { Ölçümleri }\end{array}$} & Cari oran \\
\hline ato & (Dönen Varlıklar-Stoklar)/Kısa Vadeli Yabancı Kaynaklar & & Asit-Test oran1 \\
\hline stdhz & Satışların Maliyeti / Stoklar & \multirow{3}{*}{$\begin{array}{c}\text { Etkinlik } \\
\text { Ölçümleri }\end{array}$} & Stok devir hız1 \\
\hline aldhz & Net Satıslar /Toplam Alacaklar & & Alacak devir hızı \\
\hline $\operatorname{ddh} z$ & Net Satışlar /Duran Varlıklar & & Duran varlık devir hızı \\
\hline efkm & Esas Faaliyet Kâr1/Net Satışlar & \multirow{6}{*}{$\begin{array}{c}\text { Kârlllık } \\
\text { Ölçümleri }\end{array}$} & Esas faaliyet kâr marj1 \\
\hline dönvk & Net Kâr/Dönen Varlıklar & & Dönen varlık kârlllığ 1 \\
\hline $\mathrm{nkm}$ & Net Kâr/Net Satışlar & & Net kâr marji \\
\hline özk & Net Kâr/Özsermaye & & Özsermaye kârlıllı̆̆1 \\
\hline aktfk & Net Kâr/Aktifler & & Aktif kârlılı̆g1 \\
\hline hbk & Dönem Sonu Net Kâr/Toplam Hisse Sayı & & Hisse başına kâr \\
\hline fko & Hisse Kapanış Fiyatı/Hisse Başına Kâr & \multirow{3}{*}{$\begin{array}{l}\text { Piyasa } \\
\text { Ölçümleri }\end{array}$} & Fiyat-Kazanç oranı \\
\hline pddo & $\begin{array}{l}\text { (Dolaşımdaki Toplam Hisse Sayısı x Hisse Kapanış Fiyatı)/ } \\
\text { Özsermaye }\end{array}$ & & $\begin{array}{l}\text { Piyasa değeri-Defter değeri } \\
\text { oranı }\end{array}$ \\
\hline gtr & $\begin{array}{l}\text { (Hisse Kapanış Fiyat1 }{ }_{t} \text { - Hisse Kapanış Fiyatt }{ }_{\mathrm{t}-1} / \text { Hisse Kapanış } \\
\left.\text { Fiyat1 }_{\mathrm{t}}\right) \mathrm{x} 100\end{array}$ & & Hisse senedi getirisi \\
\hline tvrlk & Ln(Dönen Varlıklar + Duran Varlıklar) & $\begin{array}{l}\text { Toplam } \\
\text { Aktifler }\end{array}$ & $\begin{array}{l}\text { Toplam varlıkların doğal } \\
\text { logaritması }\end{array}$ \\
\hline
\end{tabular}




\section{Çalışmanın Hipotezleri}

BİST Kurumsal Yönetim Endeksinde yer alan 39 işletmenin, yer almayan 151 işletmenin finansal oranları ile birlikte kullanılan kontrol değişkeninin hisse senedi getirisi üzerindeki etkisini test etmek için kurulan temel hipotezler aşağıda yer almaktadır.

$\mathrm{H}_{0}$ : Finansal oranların getiri üzerindeki etkisi anlamsızdır.

$\mathrm{H}_{1}$ : Finansal oranların getiri üzerindeki etkisi anlamlıdır.

\section{Verilerin Analizi}

Çalışma kapsamında yer alan 190 işletmeye ait 1 bağımlı ve 14 tane de bağımsız değişken kullanılarak istatistiksel analizler yapılmışır. Analizlerde bağımsız değişken olarak işletmelere ait finansal oran verileri, bağımlı değişken olarak işletmelere ait hisse senedi getirisi, kontrol değişkeni olarak ise işletmelerin toplam varlıklarının doğal logaritması alınmışır.

Çalışmada yer alan analizlerde birçok farklı alanda araştırmacılar tarafindan veri analizinde yaygin olarak kullanılan SPSS (Statistical Package for the Social Sciences) paket programı kullanılmıştır. 190 işletmenin verilerini kullanarak öncelikle bağımlı ve bağımsız değisskenlere ait tanımlayıcı istatistikler tespit edilmiş, daha sonra bağımsız değişkenlerin bağımlı değişken üzerinde etkisi olup olmadığı $\% 5$ anlamlılık düzeyinde kurulan iki farklı çoklu regresyon modeli ile sınanmıştır.

\section{Bulgular}

Yapılan analizlerde bağımlı ve bağımsız değişkenlere ait tanımlayıcı istatistikler ve bağımsız değişkenlerin bağımlı değişkenler üzerindeki etkisini tespit etmek için yapılan çoklu regresyon modelleri ve onlara ait sonuçlar aşağıda detaylı olarak sunulmuştur. Tabloda 2'de yer alan tanımlayıcı istatistiklerde Kurumsal Yönetim endeksi işletmeleri (kyi), Kurumsal Yönetim endeksinde yer almayan işletmeler ise (dişl) olarak tanımlanmıştır.

Tablo 2. Deģ̧̆̈kenlere Ait Tanmlaync İstatistikler

\begin{tabular}{|c|c|c|c|c|c|c|c|}
\hline & & $\mathbf{N}$ & Minimum & Maksimum & Ortalama & Standart Hata & Standart Sapma \\
\hline \multirow[b]{2}{*}{$\mathrm{caO}$} & kyi & 234 & 0,0000 & 5,4871 & 1,4061 & 0,0561 & 0,8577 \\
\hline & dişl & 906 & 0,0000 & 10,0336 & 1,8870 & 0,0512 & 1,5416 \\
\hline \multirow[b]{2}{*}{ ato } & kyi & 234 & 0,0000 & 16,3185 & 2,0462 & 0,1576 & 2,4108 \\
\hline & dişl & 906 & $-31,4631$ & 31,5874 & 1,6826 & 0,0835 & 2,5130 \\
\hline \multirow{2}{*}{$\operatorname{stdh} z$} & kyi & 234 & 0,0000 & 92,2969 & 10,1049 & 0,9718 & 14,8663 \\
\hline & dişl & 906 & 0,0000 & 90,0776 & 6,2800 & 0,2452 & 7,3818 \\
\hline \multirow{2}{*}{ aldhz } & kyi & 234 & 0,0000 & 79,0797 & 9,5453 & 0,8589 & 13,1386 \\
\hline & dişl & 906 & 0,0000 & 76,8739 & 5,2412 & 0,1977 & 5,9501 \\
\hline \multirow{2}{*}{ ddhz } & kyi & 234 & 0,0000 & 8,9347 & 1,8820 & 0,0987 & 1,5103 \\
\hline & dişl & 906 & 0,0000 & 9,4749 & 1,7460 & 0,0440 & 1,3254 \\
\hline \multirow{2}{*}{ efkm } & kyi & 234 & $-29,8515$ & 89,0216 & 14,2155 & 1,4805 & 22,6472 \\
\hline & dişl & 906 & $-66,7901$ & 92,8246 & 9,9162 & 0,5227 & 15,7329 \\
\hline \multirow{2}{*}{ dönvk } & kyi & 234 & $-48,3449$ & 124,7285 & 11,0935 & 1,3399 & 20,4967 \\
\hline & dişl & 906 & $-129,4560$ & 98,8722 & 8,8985 & 0,6281 & 18,9072 \\
\hline \multirow{2}{*}{$\mathrm{nkm}$} & kyi & 234 & $-49,1425$ & 103,5043 & 11,9111 & 1,3923 & 21,2980 \\
\hline & dişl & 906 & $-160,8776$ & 143,0510 & 8,0847 & 0,6941 & 20,8936 \\
\hline \multirow{2}{*}{ özk } & kyi & 234 & $-203,3104$ & 93,2777 & 10,5493 & 1,6351 & 25,0125 \\
\hline & dişl & 906 & $-78,5070$ & 93,4375 & 10,0448 & 0,5819 & 17,5155 \\
\hline \multirow{2}{*}{ aktfk } & kyi & 234 & $-31,0669$ & 42,4656 & 4,8264 & 0,5502 & 8,4168 \\
\hline & dişl & 906 & $-34,6938$ & 49,5679 & 4,5390 & 0,2587 & 7,7859 \\
\hline \multirow{2}{*}{ pddo } & kyi & 234 & 0,0000 & 16,3185 & 2,0796 & 0,1549 & 2,3695 \\
\hline & dişl & 906 & $-7,4126$ & 31,5874 & 1,7864 & 0,0714 & 2,1497 \\
\hline \multirow{2}{*}{ hbk } & kyi & 234 & $-6,6000$ & 15,3400 & 0,9244 & 0,1321 & 2,0208 \\
\hline & dişl & 906 & $-11,6800$ & 12,9600 & 0,5873 & 0,0662 & 1,9926 \\
\hline \multirow{2}{*}{ fko } & kyi & 234 & $-259,6200$ & 364,0600 & 9,1133 & 2,3660 & 36,1925 \\
\hline & dişl & 906 & $-158,9300$ & 157,3600 & 7,5351 & 0,9613 & 28,9364 \\
\hline \multirow{2}{*}{ tvrlk } & kyi & 234 & 17,3600 & 26,7400 & 22,3197 & 0,1343 & 2,0548 \\
\hline & dişl & 906 & 15,6800 & 26,8200 & 20,1170 & 0,0608 & 1,8289 \\
\hline \multirow{2}{*}{ gtr } & kyi & 234 & $-46,3900$ & 130,9100 & 12,0288 & 2,2242 & 34,0234 \\
\hline & dişl & 906 & $-81,4500$ & 268,7800 & 16,4548 & 1,6257 & 48,9329 \\
\hline
\end{tabular}


Tablo 2'de finansal oranlara ait elde edilen tanımlayıcı istatistikler yer almaktadır. Buna göre diğer işletmelerin cari oran (cao) ile hisse senedi getiri ortalamasi; Kurumsal Yönetim işletmelerine ait verilerden yüksektir. Diğer finansal oranlarda ise Kurumsal Yönetim endeksinde yer alan işletmelerin 2013-2018 dönemine ait ortalaması diğer işletmelerin ortalamasından daha yüksek olduğu gözlemlenmiştir. Elde edilen bu oranlara göre Kurumsal Yönetim endeksinde yer alan işletmelerin diğer işletmelere göre varlık ve kaynaklarını daha etkin, daha verimli şekilde kullandığını söylemek mümkündür.

\section{Çoklu Regresyon Analizi Sonuçları}

İşletmelerin hisse senedi getirilerinin bağımlı, finansal oranlar ile kontrol değişkeninin bağımsız değişken olarak alındığı çoklu regresyon analizine ait model aşağıdaki şekilde kurulmuştur.

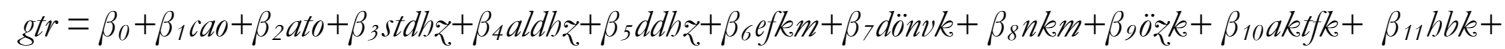

$$
\begin{aligned}
& \beta_{12} f k_{0}+\beta_{13} p d d o+\beta_{14} \text { tvrlk }+\varepsilon
\end{aligned}
$$

Yukarıda yer alan çoklu regresyon modelinde, "gtr" bağımlı değişken, " $\beta_{0}$ " regresyon analizine ait elde edilen sabit terim, " $\beta 1 \ldots \ldots . . . . . . . \beta 14$ " bağımsız değişkenlere ait regresyon katsayısı, "cao..........fko" bağımsız değişkenler (finansal oranlar), "tvrlk" doğal logaritması alınmış toplam varlıklar (kontrol değişkeni), $\varepsilon$ ise hata terimini temsil etmektedir.

İşletmelere ait hisse senedi getirilerinin bağıml, finansal oranlar ile kontrol değişkeninin bağımsız değişken olarak yer aldığı çoklu doğrusal regresyon (Linear Regresyon) analizine ait elde edilen istatistiksel sonuçlar Tablo 3 ve Tablo 4'te verilmiştir.

Tablo 3’te bağımsız değişkenler ile getiri arasındaki ilişkiyi tespit etmek için yapılan iki farklı çoklu regresyon analizinden elde edilen modellere ait özet katsayılarına yer verilmiştir. Tabloda yer alan istatistiksel değişkenlerde en önemli katsayılar $R, R^{2}$, p ve $D$-W test değerleridir. Bura da $R$ değeri bağımsız değişkenler ile bağımlı değişken arasındaki korelasyon değerini, $\mathrm{R}^{2}$ değeri bağımsız değişkenlerin bağımlı değişkeni açıklama oranını, $\mathrm{p}$ değeri \% 5 anlamlılık düzeyinde kurulan regresyon modelinin anlamlı olup olmadığını, D-W (Durbin-Watson) ise çoklu regresyon modelinde oto korelasyona ait test istatistik değerini verir.

Tablo 3. Coklu Regresyon Modeli Özet Tablosu: Getiri

\begin{tabular}{ccccccc}
\hline Model & $\mathbf{R}$ & $\mathbf{R}^{2}$ & Düzeltilmiş $\mathbf{R}^{2}$ & $\mathbf{F}$ & Olasılık Değeri (p) & D-W \\
\hline $1^{\text {a }}$ & & & 0,078 & 2,337 & $0,005^{* * *}$ & 1,625 \\
$2^{\mathrm{b}}$ & 0,222 & 0,049 & 0,034 & 3,301 & $0,000^{* * *}$ & 1,658 \\
\hline
\end{tabular}

$\mathrm{a}=$ Kurumsal Yönetim İşletmelerine Ait Finansal Oranlar (Bağımsız Değişkenler)

$\mathrm{b}=$ Diğer İşletmelere Ait Bağımsız Finansal Oranlar (Bağımsız Değişkenler)

c = Getiri (Bağımlı Değişken)

***, \%1 düzeyinde anlamlılığ1 ifade etmektedir.

Birden fazla bağımsız değişken içeren çoklu regresyon modeline ait özet verilerin yer aldığı Tablo 3’teki sonuçlara göre, bağımlı değişken olan getiri ile finansal oranlar ile kontrol değişkeninin yer aldığı bağımsız değişkenler arasındaki korelasyon katsayısını temsil eden $\mathrm{R}$ değeri kurumsal yönetim endeksinde yer alan işletmelerde (kyi) \%37, kurumsal yönetim endeksinde yer almayan işlemelerde (dişl) bu oran \%22,2'dir. Birinci model de, bağımlı değişken olan hisse senedi getirisini (gtr) kurumsal yönetim işletmelerine ait (kyi) bağımsız değişkenler \%13,7'sini $\left(\mathrm{R}^{2}\right)$ açlklarken, ikinci modelde kurumsal yönetim endeksinde yer almayan (dişl) işletmelere ait bağımsız değiş̧kenler ise getirinin \% $\%$,9'unu ( $\mathrm{R}^{2}$ ) açıkladı̆̆ tespit edilmiştir. Başka bir deyişle bağımlı değişken olan hisse senedi getirisindeki \%13,7’lik değişim (varyans) kurumsal yönetim işletmelerine ait bağımsız değişkenler tarafından açıklanırken, diğer işletmelerde ise bu oranın \% 4,9'dur.

Bağımsız değişkenlerin bağımlı değişken üzerindeki etkisinin \%95 güven aralığında anlamlı olup olmadığ Tablo 3'te yer alan $\mathrm{F}$ istatistik değerine ait $\mathrm{p}$ olasılık değeri vermektedir. Kurumsal yönetim işletmelerine ait regresyon modellinde $\mathrm{F}$ değeri 2,337, $\mathrm{p}$ değeri 0,005 , diğer işletmelerde ise $\mathrm{F}$ değeri 3,301, $\mathrm{p}$ değeri ise 0,000 çıkmıştır. Her iki modelde elde edilen p değeri 0,05 'ten küçük olduğu için kurulan regresyon modellerinin bir bütün olarak anlamlı olduğunu söylemek mümkündür. 
$\mathrm{D}$-W test istatistik değeri de ekonometrik çalışmalarda 1,5-2,5 aralı̆̆ında olduğu zaman kurulan regresyon modellerinde otokorelasyon olmadığı kabul edilmektedir. Model özeti tablosunda yer alan D-W değeri 1,625-1,658 aralığında çıtığından dolay1 her iki modelde de otokorelasyon sorunu tespit edilmemiştir. Bu sonuçlara göre her iki modelde de $\mathrm{H}_{0}$ hipotezi red edilirken, $\mathrm{H}_{1}$ hipotezi kabul edilmiştir.

Regresyon modelleri anlamlı çıktığından her iki modelde yer alan bağımlı ve bağımsız değişkenlere ait parametre katsayıları ( $\beta$ ), standart hata, standardize edilmiş regresyon katsayısı (Beta), t değeri, $\mathrm{p}$ anlamlılık düzeyi, Tolerans ve VIF değerlerine ait istatistiksel sonuçlar Tablo 4 ve Tablo 5 'te sunulmuştur.

Tablo 4. Coklu Regresyon Analizi Parametre Katsaynlar Tablosu: kyia

\begin{tabular}{|c|c|c|c|c|c|c|c|}
\hline & \multirow{2}{*}{ Regresyon Katsayisı } & \multirow{2}{*}{ Standart Hata } & \multirow{2}{*}{ Beta } & \multirow{2}{*}{$\mathbf{t}$} & \multirow[b]{2}{*}{$\mathrm{p}$} & \multicolumn{2}{|c|}{ Collinearity Statistics } \\
\hline & & & & & & Tolerance & VIF \\
\hline$\overline{\beta_{0}}$ & 21,303 & 32,031 & - & 0,665 & 0,507 & - & - \\
\hline $\mathrm{caO}$ & 3,467 & 3,745 & 0,087 & 0,926 & 0,356 & 0,471 & 2,122 \\
\hline ato & 9,370 & 6,919 & 0,214 & 1,354 & 0,177 & 0,167 & 5,972 \\
\hline $\operatorname{stdh} z$ & $-0,194$ & 0,165 & $-0,085$ & $-1,177$ & 0,241 & 0,812 & 1,231 \\
\hline aldhz & 0,592 & 0,234 & 0,228 & 2,523 & $0,012^{* *}$ & 0,515 & 1,942 \\
\hline ddhz & $-3,576$ & 2,369 & $-0,147$ & $-1,509$ & 0,133 & 0,439 & 2,279 \\
\hline efkm & $-0,100$ & 0,157 & $-0,058$ & $-0,640$ & 0,523 & 0,512 & 1,953 \\
\hline dönvk & 0,309 & 0,187 & 0,186 & 1,648 & 0,101 & 0,329 & 3,040 \\
\hline $\mathrm{nkm}$ & $-0,122$ & 0,164 & $-0,077$ & $-0,745$ & 0,457 & 0,396 & 2,524 \\
\hline özk & 0,066 & 0,160 & 0,048 & 0,412 & 0,681 & 0,302 & 3,307 \\
\hline aktfk & $-0,775$ & 0,695 & $-0,192$ & $-1,116$ & 0,266 & 0,142 & 7,038 \\
\hline pddo & $-1,840$ & 2,224 & $-0,128$ & $-0,828$ & 0,409 & 0,175 & 5,715 \\
\hline hbk & 3,431 & 1,168 & 0,204 & 2,938 & $0,004^{* *}$ & 0,869 & 1,151 \\
\hline fko & 0,014 & 0,065 & 0,015 & 0,215 & 0,830 & 0,888 & 1,126 \\
\hline tvrlk & $-0,531$ & 1,322 & $-0,029$ & $-0,402$ & 0,688 & 0,795 & 1,258 \\
\hline$a=$ Kuru & önetim Endeksinde Y & n İşletmeler (kyi) & & & & & \\
\hline
\end{tabular}

**, $\% 5$ düzeyinde anlamlllığ ifade etmektedir.

Regresyon analizine ait parametre katsayılarının yer aldığı Tablo 4'te yer alan istatistiksel sonuçlara göre, alacak devir hızı (aldhz, $\mathrm{p}=0,012)$ ile hisse başına kâr (hbk, $\mathrm{p}=0,004)$ değişkenlerine ait $\mathrm{p}$ değeri 0,05 'ten küçük çıktığından bu değiş̧kenlerin hisse senedi getirisi üzerindeki etkisi anlamlı bulunmuştur. $\mathrm{Bu}$ cümledeki ifadeler tablo 5 'te yer almaktadır.

Diğer değişkenlere ait $\mathrm{p}$ değerleri 0,05 ’ten büyük çıktığından getiri üzerindeki etkileri anlamlı bulunmamıştır. Bu bulgulardan yola çıkarak alacak devir hızı (aldhz) ile hisse başına kâr (hbk) finansal rasyolar için $\mathrm{H}_{0}$ hipotezi red, $\mathrm{H}_{1}$ hipotezi ise kabul edilmiştir. Diğer finansal rasyolar da ise $\mathrm{H}_{0}$ hipotezi kabul, $H_{1}$ hipotezi ise red edilmiştir. Ayrıca tabloda yer alan Tolerance değerleri 0,142-0,888 aralığında, VIF değerleri ise 1,151-5,972 aralığında çıkmıştır. Bu sonuca göre çoklu regresyon analizinde yer alan bağımsız değişkenler arasında çoklu doğrusal bağlantı problemine rastlanmamıştır. Elde edilen bu sonuca göre çoklu regresyon formülü şu şekilde kurulur: gtr $=21,303+0,592 \times$ aldhz $+3,431 \times$ hbk $+\varepsilon$.

Tablo 5. Coklu Regresyon Analiz̨i Parametre Katsaynlar Tablosu: dişl $l^{n}$

\begin{tabular}{|c|c|c|c|c|c|c|c|}
\hline & \multirow{2}{*}{ Regresyon Katsayısı } & \multirow{2}{*}{ Standart Hata } & \multirow{2}{*}{ Beta } & \multirow{2}{*}{$\mathbf{t}$} & \multirow{2}{*}{$\mathrm{p}$} & \multicolumn{2}{|c|}{ Collinearity Statistics } \\
\hline & & & & & & Tolerance & VIF \\
\hline$\beta_{0}$ & 18,208 & 18,294 & - & 0,995 & 0,320 & - & - \\
\hline cao & $-0,293$ & 1,221 & $-0,009$ & $-0,240$ & 0,811 & 0,721 & 1,387 \\
\hline ato & $-1,417$ & 0,710 & $-0,073$ & $-1,996$ & 0,046 & 0,803 & 1,246 \\
\hline stdhz & 0,161 & 0,243 & 0,024 & 0,660 & 0,509 & 0,793 & 1,261 \\
\hline aldhz & $-0,261$ & 0,350 & $-0,032$ & $-0,745$ & 0,456 & 0,589 & 1,699 \\
\hline ddhz & 1,707 & 1,896 & 0,046 & 0,900 & 0,368 & 0,404 & 2,473 \\
\hline efkm & $-0,139$ & 0,115 & $-0,045$ & $-1,209$ & 0,227 & 0,781 & 1,281 \\
\hline dönvk & $-0,104$ & 0,183 & $-0,040$ & $-0,566$ & 0,571 & 0,213 & 4,688 \\
\hline $\mathrm{nkm}$ & 0,121 & 0,108 & 0,052 & 1,114 & 0,266 & 0,498 & 2,006 \\
\hline özk & 0,032 & 0,171 & $-0,011$ & $-0,188$ & 0,851 & 0,285 & 3,512 \\
\hline aktfk & 0,082 & 0,524 & 0,013 & 0,156 & 0,876 & 0,154 & 6,505 \\
\hline pddo & 2,643 & 0,840 & 0,116 & 3,148 & $0,002^{* * *}$ & 0,784 & 1,275 \\
\hline hbk & 3,693 & 0,820 & 0,150 & 4,505 & $0,000^{* * *}$ & 0,958 & 1,044 \\
\hline fko & 0,159 & 0,056 & 0,094 & 2,844 & $0,005^{* * *}$ & 0,980 & 1,021 \\
\hline tvrlk & $-0,410$ & 0,889 & $-0,015$ & $-0,461$ & 0,645 & 0,966 & 1,035 \\
\hline
\end{tabular}

$\mathrm{a}=$ Kurumsal Yönetim Endeksinde Yer Almayan İsletmeler (dişl)

***, $\% 1$ düzeyinde anlamlllı̆̆ ifade etmektedir. 
Tablo 4'te yer alan çoklu regresyon analizine ait parametre katsayılarına göre, piyasa değeri defter değeri oranı (pddo, $\mathrm{p}=0,002)$, hisse başına kâr (hbk, $\mathrm{p}=0,000)$ ile fiyat kazanç oranı $(\mathrm{fko}, \mathrm{p}=0,005)$ değişkenlerine ait $\mathrm{p}$ değeri 0,05 'ten küçük çıktığından hisse senedi getirisi üzerindeki etkileri anlamlı olduğu gözlemlenmiştir. Diğer finansal rasyolara ait $\mathrm{p}$ değerleri ise 0,05 'ten büyük çıktı̆̆ından getiri üzerindeki etkileri anlamlı bulunmamıştır. Bu bağlamda piyasa değeri defter değeri oranı (pddo), hisse başına kâr (hbk) ile fiyat kazanç oranı (fko) rasyolarında $\mathrm{H}_{0}$ hipotezi red, $\mathrm{H}_{1}$ hipotezi ise kabul edilmiştir. Diğer finansal rasyolar da ise $\mathrm{H}_{0}$ hipotezi kabul, $\mathrm{H}_{1}$ hipotezi red edilmiştir. Ayrıca tabloda yer alan Tolerance değerleri 0,154-0,980 aralığında, VIF değerleri ise 1,021-6,505 aralığında çıkmıştır. Tablo 5’teki sonuçlardan yola çıarak çoklu regresyon formülü ise şu şekilde kurulur: gtr $=18,208+2,643 \times$ pddo $+3,693 \times$ hbk + $0,159 \times$ fko $+\varepsilon$. Yukarıda bahsedilen istatistiksel değerlere göre çoklu regresyon analizinde yer alan bağımsız değişkenler arasında çoklu doğrusal bağlantı problemi olmadığını söylemek mümkündür.

\section{Sonuç}

Kurumsal yönetim ilkeleri ve uygulamalarının; işletmelere yarattı̆̆ katma değer ve sağladığı faydalar oldukça fazla olmakla birlikte; en önemli katkıları; işletmeye artı değer yaratmak, olumlu imaj sağlamak, düşük maliyetli kaynak oluşturmak şeklinde sıralanmaktadır. Bu çerçevede düşünüldüğgunde kurumsal yönetim uygulamaları; işletmelerin finansal performansı üzerinde dolayısıyla getirileri üzerinde de etkiler yaratmaktadır. Buradan hareketle kurumsal yönetim endeksinde bulunan ve bulunmayan işletmelerin finansal performanslarının getirileri üzerindeki etkilerini tespit etmeyi amaçlayan çalışmanın sonuçlarını aşağıdaki şekilde sıralamak mümkündür;

- Kurumsal Yönetim endeksinde yer alan işletmelerin diğer işletmelere göre varlık ve kaynaklarını daha etkin, daha verimli ve katma değer yaratıcı şekilde kullandıkları görülmüştür.

- Regresyon analizi sonuçlarına göre; alacak devir hızı ile hisse başına kâr değişkenlerinin hisse senedi getirisi üzerindeki etkisi anlamlı bulunmuştur.

- Alacak devir hızı ile hisse başına kâr finansal rasyoları için $\mathrm{H}_{0}$ hipotezi red, $\mathrm{H}_{1}$ hipotezi ise kabul edilmiştir. Yani bu rasyoların getiri üzerindeki etkisi anlamlı çıkmıştır.

- Çoklu regresyon analizine ait parametre katsayılarına göre, piyasa değeri defter değeri oranı, hisse başına kâr ile fiyat kazanç oranı değişkenlerinin hisse senedi getirisi üzerindeki etkileri anlamlı çıkmıştır.

- Piyasa değeri defter değeri oranı, hisse başına kâr ile fiyat kazanç oranı rasyolarında $\mathrm{H}_{0}$ hipotezi red, $\mathrm{H}_{1}$ hipotezi ise kabul edilmiştir. Yani bu rasyoların getiri üzerindeki etkisi anlamlı çıkmışırı.

- Diğer finansal rasyolar da ise oranların getiri üzerindeki etkisi anlamsız kabul edilmiş ve temel hipotezlerden birini oluşturan $\mathrm{H}_{1}$ hipotezi red edilmiştir.

- Sonuç olarak Kurumsal Yönetim Endeksinde yer alan işletmelere ait finansal oranların hisse senedi getirilerini \%13,7 açıkladığı; Kurumsal Yönetim Endeksinde yer almayan işletmelerde ise aynı finansal oranların hisse senedi getirilerini \% 4,9 oranında açıkladığı tespit edilmiştir.

Yapılan çalışma kapsamında; işletmelerin kurumsal yönetim ilkelerini benimsemelerinin ve kurumsal yönetim uygulamalarına önem vermelerinin finansal performanslarına olumlu şekilde yansıdığına dair genel bir sonuca ulaşılmıştır. Bu sonuca bağlı olarak; kurumsal yönetim kavramının işletmelerin faaliyetlerine entegre edilerek hassasiyetle uygulanması yönünde çabalar gösterilmelidir. Bununla birlikte sektörler arası, ülkeler arası finansal oranları veya farklı finansal rasyoları kullanarak yapılacak araştırmalarla kavrama farklı bakış açıları kazandırılmalıdır.

\section{Etik Beyan}

"Kurumsal Yönetim Endeksinde Yer Alan Ve Yer Almayan İşletmelerde Finansal Performansın Getiri Üzerindeki Etkisinin İncelenmesi” başlıklı çalısmanın yazım sürecinde bilimsel, etik ve alıntı kurallarına uyulmuş; toplanan veriler üzerinde herhangi bir tahrifat yapılmamış ve bu çalışma herhangi başka bir akademik yayın ortamına değerlendirme için gönderilmemiştir. 


\section{Kaynakça}

Aksu, M. ve Aytekin, S. (2015). Kurumsal yönetim ilkelerine uyum notu ile hisse senedi getirisi ilişkisi: BİST kurumsal yönetim endeksi (XKURY) üzerine bir uygulama. Gümüshane Üniversitesi Sosyal Bilimler Elektronik Dergisi, 6(13), 201-219.

Azeem, M., Hassan, M. ve Kouser, R. (2013). Impact of quality corporate governance on firm performance: A ten year perspective. Pakistan Journal of Commerce and Social Sciences, 7(3), 656-670.

Bebzcuk, R. N. (2005). Corporate Governance and Ownership: Measurement and Impact on Corporate Performance and Dividend Policies in Argentina. Latin American Research Network. Working Paper, R-5/16:1-59.

Cheng, S. (2008). Board size and the variability of corporate performance. Journal of Financial Economics, 87, 157-176.

Ersoy, E., Bayrakdaroğlu, A. ve Şamiloğlu, F. (2011). Türkiye'de kurumsal yönetim ve firma performansı (Tobin-Q ve Anormal Getiri) arasındaki ilişkinin analizi. Finans Politik \& Ekonomik Yorumlar, 48(554), 71-84.

Eyüboğlu, K. (2011). Kurumsal yönetimin hisse senedi getirileri üzerindeki etkisi: İMKB kurumsal yönetim endeksindeki şirketler açısından bir değerlendirme. Karadeniz. Teknik Üniversitesi Sosyal Bilimler Enstitüsü Dergisi, 1 , 55-69.

Gompers, P., Ishi1, J. ve Metrick, A. (2003). Corporate governance and equity prices. The Quarterly Journal of Economics, 118, 107-155.

Hart, O. (1995). Corporate governance: Some theory and implications. The Economic Journal, 105(430), 678-689.

Kılıç, S. (2011). İMKB kurumsal yönetim endeksine dâhil olan şirketlerin getiri performanslarının ölçülmesi. Finans Politik \& Ekonomik Yorumlar, 48(552), 45-58.

Niu, F. F. (2006). Corporate governance and the quality of accounting earnings: A Canadian perspective. International Journal of Managerial Finance, 2(4), 302-327.

Oral, T., Polat, E. ve Şit, A. (2017). Borsa İstanbul kurumsal yönetim endeksinde yer alan şirketlerin sermaye yapıları ile hisse senedi getirileri arasındaki ilișkinin incelenmesi. Akademik Yaklașımlar Dergisi, 8(1), 126-141.

Öztürk, M. B. ve Demirgüneş, K. (2008). Kurumsal yönetim bakış açısıyla entelektüel sermaye. Selçuk Üniversitesi Sosyal Bilimler Enstitüsü Dergisi, 19, 395-411.

Sakarya, Ş., Yazgan, K. F. ve Yıldırım, H. H. (2017). Kurumsal Yönetim derecelendirmesinin hisse senedi performansına etkisi: BİST kurumsal yönetim endeksi üzerine bir inceleme. Sosyal ve Beşeri Bilimler Araștırmalar Dergisi, 18(40), 55-76.

Shen, C. H. ve Lin, K. L. (2010). The impact of corporate governance on the relationship between fundamental information analysis and stock returns. Emerging Markets Finance and Trade, 46(5), 90-105.

Şengür, E. D. ve Püskül, A. S. (2011). İMKB kurumsal yönetim endeksindeki şirketlerin yönetim kurulu yapıs1 ve işletme performansının değerlendirilmesi. Dumlupınar Üniversitesi Sosyal Bilimler Dergisi, 31, 33-50.

Tanriyar, İ. (2019) Neden kurumsal yönetim? İlhan Tanriyar; http://www.agdem.com/index.php?option,nedenkurumsal-yoenetim,lhan-tanriyar; Erişim Tarihi: 26.02.2019.

Tetik, N. (2013). Kurumsal yönetim ilkeleri ve yeni Türk ticaret kanunu düzenlemelerinin işletmelerin finansal yönetimi üzerinde etkileri. İönü University International Journal of Social Sciences, 2(1), 43-58.

Tsai, M. T. ve Tung, W. H. (2014). Corporate governance, resources, FDI commitment and firm performance: empirical analyses of Taiwanese high-tech firms. Chinese Management Studies, 8(3), 313-332.

Ulukan, C. (2004). Aile işletmeleri kurumsal yönetim için ne kadar hazır? Eskişehir'de faaliyet gösteren aile işletmeleri üzerine bir araştırma. I. Aile Issletmeleri Kongresi. İstanbul Kültür Üniversitesi, İktisadi ve İdari Bilimler Fakültesi, Aile İşletmeleri ve Girișimcilik Araştırma Merkezi, 17-18 Nisan, İstanbul.

Yavuz, S., Yıldırım, S. ve Elmas, B. (2015). Kurumsal yönetim endeksi ile şirket hisse senedi getiri ilişkisi: BİST’de bir uygulama. Erżincan Üniversitesi Sosyal Bilimler Enstitüsü Dergisi, 8(2), 73-82.

Yenigün, T. (2008). Kurumsal yönetim ve işletme içi denetim (Yüksek Lisans Tezi). Dokuz Eylül Üniversitesi Sosyal Bilimleri Enstitüsü, İzmir.

Zuva, J. ve Zuva, T. (2018). Corporate governance and organisational performance. International Journal of Business and Management Studies, 10(1), 16-29.

\section{EXTENDED ABSTRACT}

In recent years, the concept of corporate governance, which has gained considerable importance both in domestic and foreign literature and in the business world; It is known as good management practices and creates serious advantages for businesses.

Corporate governance principles and practices; Although the added value it creates to businesses and then to all business circles and the benefits it provides are quite high; The most important contributions are collected under three headings. These; creating added value to the business, providing a positive image, creating low-cost resources. In this context, corporate governance practices; It also has a variety of effects on the financial performance of enterprises and thus on their returns. From this point of view, the study in question; The purpose of this study is to determine the effects of the financial performance of the other companies that are included in the corporate governance index and which are not included in the corporate governance index, on their returns. For this purpose, the enterprises examined in the scope of 
the study; two groups. The first group includes the companies listed in the BIST Corporate Governance (XKURY) Index and the second group includes the enterprises not included in the BIST Corporate Governance Index. The main starting point of the study is to analyze the effects of financial ratios of these two groups on stock returns and to determine if there is a difference. In this context, in this study, fourteen financial ratios and one control variable are used as liquidity, efficiency, profitability and market measurements.

In the analysis, five-year data of enterprises for 2013-2018 period were obtained and used. One hundred ninety enterprises whose data are continuous during the review period are included in the research. Thirty-nine of these enterprises are included in the Corporate Governance Index and one hundred and fifty of them are not included in the Corporate Governance Index. The financial ratios and control variables of the enterprises were analyzed as independent and stock returns as dependent variables and analyzed using two different regression models.

According to the results obtained from these analyzes; It was seen that the financial ratios of the companies included in the Corporate Governance Index explained the stock returns by $13.7 \%$, while the same financial ratios explained the stock returns of the companies by $4.9 \%$. In addition to this basic result, it is possible to list the other results as follows;

- It is seen that the companies included in the Corporate Governance Index use their assets and resources in a more effective, more efficient and more value-added way than the other enterprises not included in the index.

- According to the results of regression analysis; the effect of the turnover rate and profit per share on the return on stock was significant.

- $\mathrm{H}_{0}$ hypothesis is rejected and $\mathrm{H}_{1}$ hypothesis is accepted for receivables transfer rate and profit per share financial ratios. In other words, the effect of these ratios on return was significant.

- According to the parameter coefficients of the multiple regression analysis, the effects of market value book value ratio, profit per share and price gain ratio variables on stock returns were significant.

- $\mathrm{H}_{0}$ hypothesis is rejected and $\mathrm{H}_{1}$ hypothesis is accepted in market value book value ratio, profit per share and price gain ratio ratios. In other words, the effect of these ratios on return was significant.

- In other financial ratios, the effect of the ratios on return is considered meaningless and $\mathrm{H}_{1}$ hypothesis, which constitutes one of the main hypotheses, is rejected.

- As a result, the financial ratios of the companies included in the Corporate Governance Index explained the stock returns by $13.7 \%$; In the companies not included in the Corporate Governance Index, it was found that the same financial ratios explained stock returns by $4.9 \%$.

Within the scope of this study; It can be said that the general conclusion reached that the adoption of corporate governance principles and giving importance to corporate governance practices positively reflected to their financial performance. Depending on this basic result; it is a clear fact that efforts should be made to implement the concept of corporate governance with precision in an integrated manner to the activities of the enterprises. However, different perspectives should be gained by researches using different cross-sectoral, different cross-country financial ratios or different kinds of financial ratios. In this way, the concept of corporate governance will gain the value it deserves both in local and international arena and will continue to create advantages for both businesses and the business world. 